\title{
Assessment of Winter Injury in Grape Cultivars and Pruning Strategies Following a Freezing Stress Event
}

\author{
Imed E. Dami, ${ }^{1 *}$ Said Ennahli, ${ }^{2}$ and Yi Zhang ${ }^{3}$
}

\begin{abstract}
Extreme subfreezing temperatures occurred in January 2009 throughout the grapegrowing regions east of the Rocky Mountains. In Ohio, temperature lows ranged between -22 and $-31^{\circ} \mathrm{C}$, which were considered critical for grapevine productivity and survival. A statewide survey was conducted to assess bud injury in more than 30 cultivars grown at research and commercial vineyards. A pruning study was also conducted at the research vineyard located in Wooster, Ohio, where Vitis vinifera Pinot gris sustained $\sim 90 \%$ bud injury after exposure to $-26^{\circ} \mathrm{C}$. The objectives of the pruning study were to evaluate various pruning strategies and to identify the best pruning practice for a rapid vine recovery. Pruning consisted of four treatments with increasing buds retained per vine. Winter injury assessment showed the greatest bud injury in the sensitive cultivars of Vitis vinifera and the least injury in new hybrid and American cultivars. Cordons, trunks, and whole vines also sustained winter injury, but there were no differences among the pruning treatments. Yield increased and cane pruning weights decreased with decreasing pruning severity resulting in unbalanced grapevines from all treatments except the 5-node hedging treatment. Furthermore, there was no negative carry-over effect of pruning type on bud fruitfulness in the subsequent year. It was concluded that even though pruning had no physiological impact on vine recovery following extensive winter injury, 5-node hedging is recommended for practical and economic reasons.
\end{abstract}

Key words: cold hardiness, hedging, Pinot gris, primary bud injury, pruning, shoot collapse

Winter extreme low temperatures can cause significant economic losses to grape production by substantially decreasing yield and fruit quality and increasing cost of production due to retraining and replacing dead vines (Wolfe 2001, Zabadal et al. 2007). A total loss of $\$ 63.6$ million in the New York wine industry was reported due to a single freeze event in 2004, and the estimated total cost of replacing dead grafted Vitis vinifera and hybrids was $\$ 155 /$ vine and $\$ 126 /$ vine, respectively (Zabadal et al. 2007). In 2007, low temperature injury of small fruit crops including grapes occurred in 21 states, causing nearly $\$ 1$ billion in economic losses (Warmund et al. 2008).

The extent of winter injury in grapevines is dependent on genotype, environment, and cultural practices (Zabadal et al. 2007). Cold hardiness expressed as LT50, which is defined as the highest temperature that kills 50 percent of the primary bud population in midwinter, varies substantially among

\footnotetext{
${ }^{1}$ Associate Professor, ${ }^{2}$ Research Associate, and ${ }^{3}$ Graduate Research Associate, Department of Horticulture and Crop Science, Ohio State University, Agricultural Research and Development Center, 1680 Madison Avenue, Wooster, OH 44691.

*Corresponding author (email: dami.1@osu.edu)

Acknowledgments: Financial support for this work was provided by the Ohio Department of Agriculture-Ohio Grape Industries Committee and the Department of Horticulture and Crop Science, the Ohio State University.

Technical assistance of cane collection and bud injury assessment provided by staff and students in I. Dami's lab and by Greg Johns and his crew at the Ashtabula Agricultural Research Station in Kingsville is acknowledged and greatly appreciated.

Manuscript submitted Aug 2011, revised Aug 2011, Oct 2011, accepted Oct 2011 Copyright $(2012$ by the American Society for Enology and Viticulture. All rights reserved.
}

doi: 10.5344/ajev.2011.11040 grape cultivars, ranging from -15 to $-30^{\circ} \mathrm{C}$ or lower (Zabadal et al. 2007). Furthermore, a given grapevine may sustain differential freezing injury in buds, canes, cordons, or trunks. Bud tissues are the most sensitive to freezing stress among grapevine parts (Zabadal et al. 2007). Within the compound bud, injury typically occurs in the primary bud first followed by the secondary and tertiary buds (Quamme 1986, Zabadal et al. 2007). The environment also affects the level of grapevine injury. Climate, including continentality, latitude, and altitude, has the most impact on winter injury (Dami et al. 2005, Wolf and Boyer 2001, Zabadal et al. 2007). Within a specific site or mesoclimate, the time of the dormant season, preceding temperatures, absolute minimum temperature, and duration of exposure all affect the severity of winter injury (Hamman et al. 1996, Zabadal et al. 2007). Cultural practices also influence winter injury, including vineyard site preparation, control of crop level, and maintenance of vine health (Howell 1988, Zabadal et al. 2007).

Following winter injury, the primary goal of a grower is to conduct cultural practices that restore the vineyard to full production with minimum cost and without sacrificing vine health and fruit quality. Among the early and most critical cultural practice is pruning adjustment (Zabadal et al. 2007). The appropriate pruning strategy will depend on the extent of primary bud injury. Therefore, an assessment of primary bud injury prior to pruning is an important step. Because extreme freezing events are infrequent, little research has been accomplished regarding the best pruning strategies for optimum grapevine recovery. With the exception of reports from Washington State describing how to deal with winter injured own-rooted $V$. vinifera vines, there is no published research on grafted $V$. vinifera grown in the eastern United States. Furthermore, growers typically respond to extensive winter injury 
by bypassing pruning altogether. Growers anecdotally assume major crop losses as a result of winter injury and thus reduce production costs by minimizing cultural practices such as pruning (Dami, author's unpublished data, 2005). This study was initiated to take advantage of the natural freezing event that occurred in January 2009 and to address the lack of information on the above issue. The specific objectives were to assess the extent of winter injury through surveying different grape cultivars in different locations in Ohio and to evaluate various pruning strategies of a cultivar that sustained extensive winter injury and eventually identify the best method of pruning to recommend to commercial growers.

\section{Materials and Methods}

Bud injury assessment. Following extreme minimum temperatures on 15-17 Jan 2009, dormant canes of more than 30 cultivars were collected randomly from commercial vineyards and the Ohio State University (OSU) research vineyards in Kingsville and Wooster, Ohio. Ten canes with 10 buds each (node position 3-12) totaling 100 buds per cultivar were collected. Canes were allowed to thaw at room temperature and buds were excised cross-sectionally with a sharp, singleedged razor blade while viewed under a lens to assess injury of primary buds. Primary buds were rated injured if they appeared brown or black and rated alive if they were green. The percentage of primary bud injury for each cultivar was computed. Given similar findings, only winter injury of cultivars grown in the research vineyards is reported.

Pruning adjustment. A pruning experiment was conducted on Vitis vinifera Pinot gris planted in 1994 at the OSU research vineyard in Wooster (lat: $40^{\circ} 47^{\prime} \mathrm{N}$; long: $81^{\circ} 55^{\prime} \mathrm{W}$; $311 \mathrm{~m}$ asl), which experienced a minimum temperature of $-26^{\circ} \mathrm{C}$ on 15 Jan 2009 (Figure 1, Figure 2). Grapevines were spaced $1.5 \mathrm{~m}$ between vines and $3 \mathrm{~m}$ between rows, trained

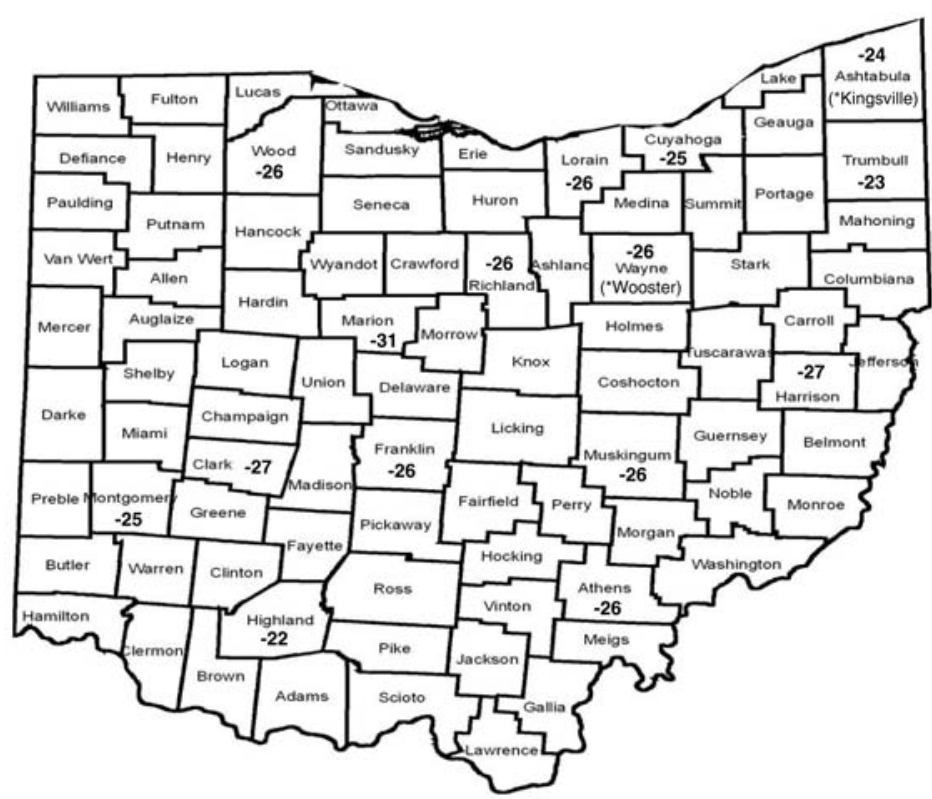

Figure 1 Minimum temperatures recorded on 15-17 Jan 2009 in Ohio. OSU research vineyards marked with asterisks $\left(^{*}\right)$ are located in Wooster (Wayne County) and Kingsville (Ashtabula County). to a bilateral cordon system, and vertically shoot-positioned. Due to the extent of injury, vines in Wooster were used for the pruning experiment. Among the pruning treatments, cane pruning was purposely not included due to its poor performance for vine recovery (Wolfe 2001), and it is not recommended following winter injury (Dami 2009). Bud injury was assessed in the Pinot gris block prior to applying the following four pruning treatments in March 2009: (1) spur pruning (standard) consisted of retaining 16 nodes/meter of cordon, (2) 2-node hedging consisted of hedging canes to 2-node spurs, with all spurs retained, (3) 5-node hedging consisted of hedging canes to 5 -node spurs, with all spurs retained, and (4) no pruning. Spur lengths were $\sim 15 \mathrm{~cm}$ for treatments 1 and 2, and $30 \mathrm{~cm}$ for treatment 3 . Each treatment was applied on 10 vines per replicate and the treatments were arranged as a randomized complete block design with six blocks. Winter injury was also monitored in August 2009, by further assessing the vascular tissue injury in cordons and trunks. The fifth and sixth vines in the row per replicate were assessed for vascular injury. Cordons were cut cross-sectionally from each end of the vine and continued toward the trunk. Phloem and xylem browning indicated vascular tissue damage (Zabadal et al.
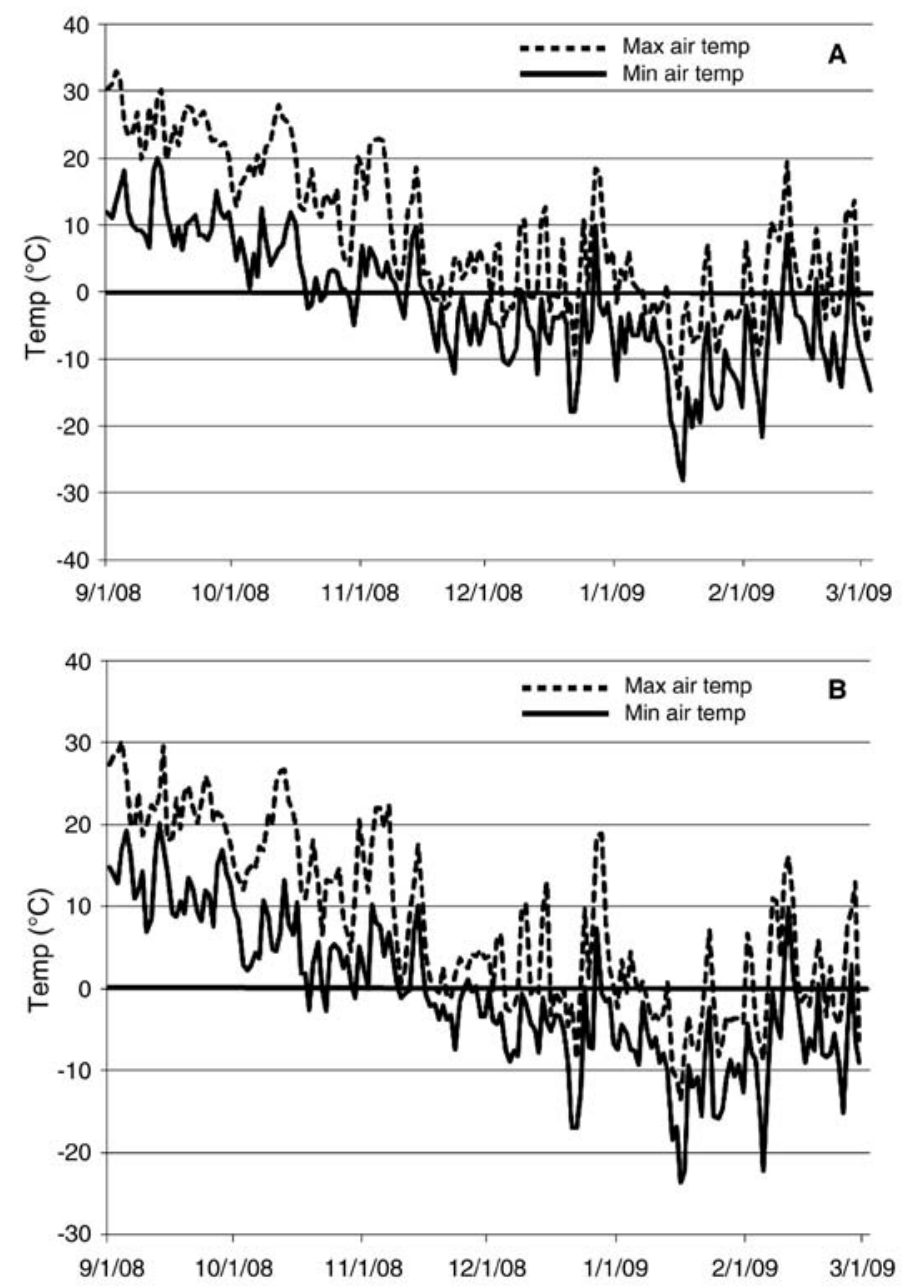

Figure 2 Daily minimum and maximum temperatures recorded from Sept 2008 to Feb 2009 at OSU research vineyards in (A) Wooster and (B) Kingsville, $\mathrm{OH}$. 
2007). Trunk damage was assessed by making $\sim 4 \mathrm{~cm}$ longitudinal cuts under the bark at $\sim 50 \mathrm{~cm}$ aboveground. Counts and percentage of damaged cordons, trunks, and whole vines were recorded.

At harvest, cluster number and yield per vine were recorded and cluster weight was computed. To assess carryover effects of the 2009 winter injury, the study was continued in 2010 to assess vine recovery. The objectives of year 2 were to assess vine recovery after returning to normal pruning practices. In 2010 , the minimum temperature dropped to $-18^{\circ} \mathrm{C}$ on 8 Feb 2010. Prior to pruning, the primary bud injury among treatments was not different and averaged 5\%, which was judged conducive to normal cropping (Table 1). Therefore, all vines from all treatments were pruned similarly and back to the standard spur pruning by retaining 16 nodes per meter of cordon. Pruning duration and weight of 1- and 2-year-old wood were determined. Pruning weights of 1-year-old wood (i.e., canes) were used to calculate the Ravaz index (RI) as the ratio of crop to cane pruning weight. The numbers of count buds and clusters per vine were recorded in 2010 to assess whether pruning treatments affected bud fruitfulness (ratio of clusters to count buds). Count shoots (CS) originating from count buds and noncount shoots (NCS) originating from buds other than count buds were also recorded.

Statistical analysis. Analysis of variance was carried out using the general linear models procedure (PROC GLM) from the SAS statistical package (SAS Institute, Cary, NC). When treatments were significantly different, an LSD test was used for mean comparisons at $p \leq 0.05$.

\section{Results and Discussion}

Bud injury assessment. Extreme subfreezing temperatures occurred in January 2009 throughout the grapegrowing regions east of the Rocky Mountains, including Illinois, Indiana, Iowa, Minnesota, and Missouri. In Ohio, temperatures dropped below $-22^{\circ} \mathrm{C}$ on $15-17$ Jan and reached $-31^{\circ} \mathrm{C}$ (Figure 1). These temperatures were the lowest recorded since 1994 (Bordelon et al. 1997). Temperatures recorded at the OSU weather stations ranged from -18 to $-28^{\circ} \mathrm{C}$ in northeastern, -22 to $-28^{\circ} \mathrm{C}$ in northwestern, -22 to $-26^{\circ} \mathrm{C}$ in central, and -16 to $-20^{\circ} \mathrm{C}$ in southern Ohio. At the two research vineyards, temperatures dipped to $-26^{\circ} \mathrm{C}$ in Wooster and $-24^{\circ} \mathrm{C}$ in Kingsville (Figure 1, Figure 2). In northeast Ohio, along the Lake Erie

Table 1 Bud and vascular winter injury of Pinot gris grapevines grown at the research vineyard in Wooster, $\mathrm{OH}$, following exposure to low temperatures in 2009 and 2010.

\begin{tabular}{|c|c|c|c|c|c|}
\hline \multirow[b]{2}{*}{ Treatment } & \multicolumn{2}{|c|}{ Primary bud injury } & \multicolumn{3}{|c|}{ Vascular injury $2009^{a}$} \\
\hline & $\begin{array}{l}2009 \text { after } \\
-26^{\circ} \mathrm{C}(\%)\end{array}$ & $\begin{array}{l}2010 \text { after } \\
-18^{\circ} \mathrm{C}(\%)\end{array}$ & $\begin{array}{c}\text { Cordon } \\
(\%)\end{array}$ & $\begin{array}{c}\text { Trunk } \\
(\%)\end{array}$ & $\begin{array}{l}\text { Vine } \\
(\%)\end{array}$ \\
\hline Spur pruning & 88 & 4 & 2 & 17 & 19 \\
\hline 2-node hedging & 87 & 4 & 3 & 14 & 18 \\
\hline 5-node hedging & 86 & 6 & 5 & 5 & 12 \\
\hline No pruning & 89 & 6 & 5 & 17 & 24 \\
\hline$p$ value ${ }^{b}$ & ns & ns & ns & ns & ns \\
\hline
\end{tabular}

aVascular injury assessment described in Materials and Methods.

${ }^{b} \mathrm{~ns}$ indicates not significant. shores where the majority of commercial $V$. vinifera cultivars are grown, temperatures ranged from -23 to $-29^{\circ} \mathrm{C}$. These extreme low temperatures are considered critical for grapevine productivity and survival (Zabadal et al. 2007).

As expected and due to the colder temperature, the same cultivars in both vineyards sustained more severe bud injury in Wooster than in Kingsville (Figure 3). For example, Cabernet franc, Chardonnay, Pinot gris, and Traminette recorded 98, 93, 87, and 40\% bud injury in Wooster and 54, 25,9 , and $11 \%$ bud injury in Kingsville, respectively (Figure 3). These differences in bud injury were attributed primarily to variation in minimum temperatures in both locations. Differences in primary bud injury associated with different temperatures in different locations were also reported in other regions (Bordelon et al. 1997, Wolfe 2001). A difference of two degrees Celsius between Wooster (colder site) and Kingsville resulted in a two- to ten-fold increase in bud injury for Cabernet franc and Pinot gris, respectively. In both sites, $V$. vinifera cultivars sustained the most injury followed by old and new hybrids; Vitis labrusca Concord sustained the least injury. In each site, cultivars and selections exhibited substantial variation in primary bud injury (Figure 3). In Wooster $\left(-26^{\circ} \mathrm{C}\right), V$. vinifera cultivars averaged $93 \%$ bud injury. Among the old hybrid cultivars, Chambourcin sustained the most injury $(93 \%)$, which was similar to $V$. vinifera cultivars, followed by Vidal and Seyval. Newly developed hybrid cultivars and advanced selections from the grape breeding programs at Cornell University and University of Minnesota sustained bud injury of 12 to $35 \%$ and 8 to $14 \%$, respectively. In Kingsville $\left(-24^{\circ} \mathrm{C}\right)$, similar trends were observed, with $V$. vinifera cultivars being the most cold-sensitive followed by the new hybrid Traminette and the most cold-hardy $V$. labrusca Concord. We also observed a better separation of bud injury among $V$. vinifera cultivars. Another observation was the unexpected performance of $V$. vinifera with an average bud injury of only $42 \%$ after exposure to $-24^{\circ} \mathrm{C}$.

In addition, the survey data collected from commercial vineyards in the same region showed similar patterns of bud injury among species and cultivars (data not shown). Furthermore, cold hardiness of several genotypes based on observations from natural freezing events is in agreement with that from simulated freezing tests using thermal analysis (Wolf and Cook 1994). According to Zabadal et al. (2007), critical temperatures, measured as LT50, are usually -18 to $-22^{\circ} \mathrm{C}$ for the tender cultivars (Chardonnay, Cabernet Sauvignon, Pinot gris, Pinot noir), -21 to $-23^{\circ} \mathrm{C}$ for the moderately tender (Cabernet franc, Riesling), -23 to $-26^{\circ} \mathrm{C}$ for the moderately hardy (Chardonel, Traminette), -26 to $-29^{\circ} \mathrm{C}$ for the hardy $V$. labrusca (Concord), and -29 to $-34^{\circ} \mathrm{C}$ for the very hardy new hybrids (Frontenac and LaCrescent). In contrast to trunk loss and vine dieback of most $V$. vinifera cultivars after exposure to $-26^{\circ} \mathrm{C}$ in Washington (Wolfe 2001), minimal trunk damage or dieback was observed in the Wooster vineyard after exposure to the same $-26^{\circ} \mathrm{C}$. This better than expected freezing tolerance is attributed to the timing of the extreme minimum temperature which occurred at an acclimation stage when vines were at their maximum cold hardiness in mid-January 
(Figure 2). Furthermore, minimum temperatures were below freezing for many days $\left(16\right.$ days below $0^{\circ} \mathrm{C}, 4$ days below $-5^{\circ} \mathrm{C}$, and 11 days below $-10^{\circ} \mathrm{C}$ in Wooster) prior to the extreme cold event. This has been shown to increase cold hardiness of vines when they were preconditioned with subfreezing temperature (Quamme 1986, Wolf and Pool 1987).

Finally, grapevines in both locations had ideal cold acclimation conditions during the previous fall of 2008 (Dami 2009). Pinot noir and Pinot gris performed the best among $10 \mathrm{~V}$. vinifera cultivars grown in Kingsville, which may be attributed to the early to midseason ripening nature of these cultivars, whereby the postharvest leaves continued to produce photosynthates that may have contributed to an increase in the reserves needed for full cold acclimation prior to the killing frost. That may not be the case with late-ripening cultivars such as Cabernet franc, in which postharvest photosynthates make little contribution due to the short period between harvest and the killing frost. Similar observations were made in Michigan (Howell 2001).

Pruning adjustment. In spring 2009, the no pruning treatment visually resulted in the earliest and most vigorous growth, whereas spur pruning had the latest and weakest, and hedge pruning treatments were intermediate (Dami and Ennahli 2010). In July and August 2009, we also observed the so-called midsummer vine collapse. Vine collapse occurred preveraison through postveraison and consisted of leaf wilting and shoot collapse in a portion of the cordon (partial collapse) or whole vine (total collapse) (Dami and Ennahli 2010). Such collapse is an indicator of vascular damage including phloem, xylem, and even cambium tissues (Goffinet 2001, Zabadal et al. 2007). Since precipitation was abundant $(625 \mathrm{~mm})$ during the growing season (growing degree days, base $10^{\circ} \mathrm{C},=1424$ ) and adjacent and noninjured cultivars in the vineyard block did not collapse, it was concluded that shoot collapse was not a result of drought, but rather a freezing stress inducedinjury in the vascular system of grapevines. The assessment of cordon, trunk, and whole vine injuries confirmed vascular damage (Table 1). Although nonpruned vines sustained the most injury, there were no statistical differences among treatments. This lack of statistical significance was attributed to the large variability of winter injury among treatment replications as a result of the sporadic nature of injury distribution and severity in the vineyard block. This random pattern of winter injury incidence was also observed in other regions in Ohio (Dami, author's personal observations, 2009). Midsummer collapse due to vascular damage has been previously observed in other grape cultivars and regions (Zabadal et al. 2007). The loss of vascular function typically begins in the phloem tissues (outer to inner) and progresses to the xylem tissues (inner to outer). Phloem injury prevents carbohydrate movement while xylem injury leads to filling of vessels with gums, which block water and nutrient flow resulting in shoot wilting and collapse (Goffinet 2001, Zabadal et al. 2007). Our findings concur with those of Keller and Mills (2007), who concluded no effect of pruning on vine survival in coldinjured Merlot vines grown in Washington.

At harvest and as expected, nonpruned vines had the highest number of clusters and yield per vine, and spur-pruned and

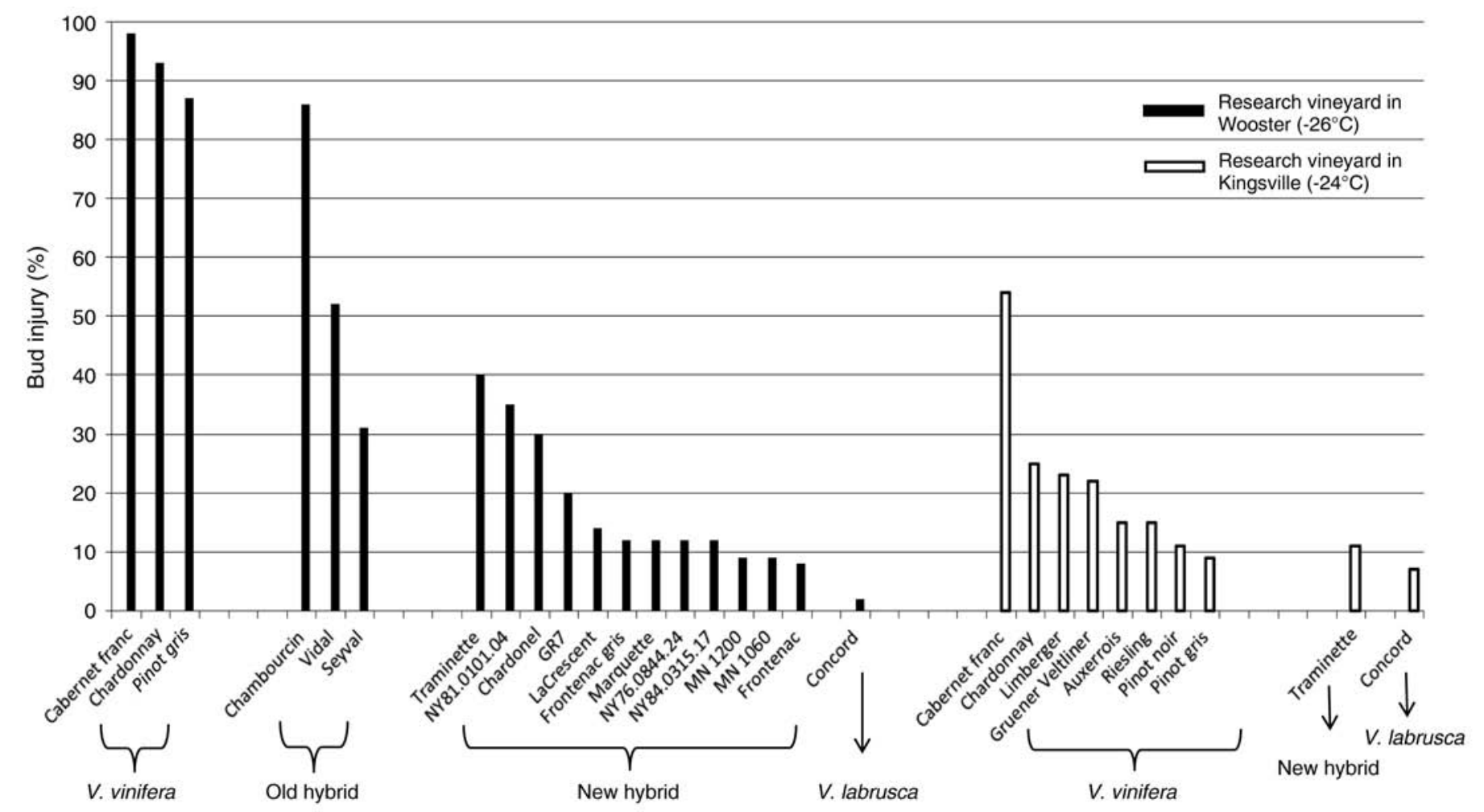

Figure 3 Primary bud injury of winegrape cultivars and selections grown at the OSU research vineyards in Wooster and Kingsville, OH, following freezing events in January 2009. 
2-node hedge pruned vines had the lowest; cluster number and yield in 5-node hedging were intermediate (Table 2). In other words, the higher the pruning severity, the lower the yield. These findings concur with previous reports from Washington where pruning severity after winter injury dictated yield (Keller and Mills 2007, Wolfe 2001). Since bud and vascular injuries were not different among treatments, it is suggested that the yield response is attributed to pruning severity rather than to cold injury.

As predicted, it took the least time to prune and remove wood from the trellis with the spur-pruning treatment and the most time with the nonpruned and 5-node hedged treatments (Table 2). Vine size, expressed as pruning weight of 1-yearold wood, was smallest in nonpruned vines and largest in the remaining treatments. Furthermore, most of the 2-year-old wood was removed from nonpruned vines and the weight decreased as pruning severity increased. However, the weight of total wood (1- and 2-year-old) removed during pruning was not different among all treatments. When expressed per linear cordon length, pruning weights of 1-year-old wood ranged from 0.22 to $0.49 \mathrm{~kg} / \mathrm{m}$. Smart and Robinson (1991) have suggested that a balanced vine has an optimal pruning weight of 0.3 to $0.6 \mathrm{~kg} / \mathrm{m}$ of row length. Based on that premise, all pruned vines were within the optimal range except for nonpruned vines, which were below the optimal range and thus were considered out of balance.

The Ravaz index (RI) was also determined based on 1 -year-old wood. Nonpruned vines had the highest RI and spur-pruned and 2-node hedged vines had the lowest (Table 2). It has been suggested that an RI value between 4 and 10 was ideal and indicated balanced vines, while a value outside that range was out of balance, with values $>10$ indicating overcropping and values $<4$ indicating undercropping or overvigor (Kliewer and Dokoozlian 2005, Smart and Robinson 1991). Based on those recommendations, it was concluded that nonpruned vines were overcropped, spur-pruned and 2-node hedged vines were undercropped, and 5-node hedged vines were balanced, as the RI was within the ideal range.

In year 2, the goal was to reestablish spurs in the vicinity of the cordons. Therefore, pruning involved removal of 1 -year-old canes as well as misplaced 2-year-old wood. It was not always possible to have 2-node spurs spaced evenly on the cordons since some were dead. By focusing on bringing spurs as close to the cordon as possible, some treatments resulted in uneven numbers of spurs thus uneven numbers of buds per vine. As a result, count buds were the lowest in nonpruned vines and the highest in the 2-node hedged vines (Table 3). Total shoots per vine followed the same trend as count buds and were directly influenced by count shoots, as noncount shoot number was the same among all treatments. Total cluster count per vine was also influenced by the total shoots per vine and was lowest in nonpruned vines and highest in spur-pruned and 2-node hedged vines. However, bud fruitfulness in 2010 was not affected by pruning treatments applied in 2009. Therefore, it is suggested that there is no carryover effect of pruning type after winter injury that

Table 2 Effect of pruning methods on yield components and vegetative growth of Pinot gris grapevines during the 2009 season.

\begin{tabular}{|c|c|c|c|c|c|c|c|c|c|}
\hline Treatment & $\begin{array}{c}\text { Cluster } \\
\text { no. }\end{array}$ & $\begin{array}{c}\text { Yield /vine } \\
(\mathrm{kg})\end{array}$ & $\begin{array}{c}\text { Cluster wt } \\
\text { (g) }\end{array}$ & $\begin{array}{c}\begin{array}{c}\text { Pruning } \\
\text { duration } \\
\text { /vine (min) }\end{array} \\
\end{array}$ & $\begin{array}{c}\text { Pruning wt } \\
\text { 1-yr wood } \\
\text { (kg/vine) }\end{array}$ & $\begin{array}{l}\text { Pruning wt } \\
1-y r \text { wood } \\
\text { (kg/m cordon) }\end{array}$ & $\begin{array}{l}\text { Pruning wt } \\
2-y r \text { wood } \\
\text { (kg/vine) }\end{array}$ & $\begin{array}{c}\text { Total } \\
\text { pruning wt } \\
\text { (kg/vine) }\end{array}$ & $\begin{array}{l}\text { Ravaz } \\
\text { index }^{b}\end{array}$ \\
\hline Spur pruning & $7 c^{c}$ & $0.7 \mathrm{c}$ & 114 & $2.0 \mathrm{~b}$ & $0.61 \mathrm{a}$ & $0.41 \mathrm{a}$ & $0.01 \mathrm{~b}$ & 0.62 & $1.1 \mathrm{c}$ \\
\hline $\begin{array}{l}\text { 2-node } \\
\text { hedging }\end{array}$ & $4 \mathrm{c}$ & $0.6 \mathrm{c}$ & 110 & $2.5 a b$ & $0.73 \mathrm{a}$ & $0.49 a$ & $0.05 \mathrm{~b}$ & 0.77 & $0.8 \mathrm{c}$ \\
\hline $\begin{array}{l}\text { 5-node } \\
\text { hedging }\end{array}$ & $17 \mathrm{~b}$ & $2.2 \mathrm{~b}$ & 126 & $2.8 \mathrm{a}$ & $0.52 \mathrm{a}$ & $0.35 a$ & $0.14 \mathrm{~b}$ & 0.67 & $4.2 \mathrm{~b}$ \\
\hline No pruning & $39 a$ & $4.5 \mathrm{a}$ & 124 & $2.8 \mathrm{a}$ & $0.33 \mathrm{~b}$ & $0.22 b$ & $0.49 a$ & 0.82 & $13.6 \mathrm{a}$ \\
\hline$p$ value & $<0.001$ & $<0.001$ & ns & 0.048 & ns & ns & $<0.001$ & ns & $<0.001$ \\
\hline
\end{tabular}

aTotal pruning weight: pruning weight of 1 - and 2-year-old wood.

${ }^{\mathrm{b}}$ Ravaz index: ratio of yield and 1 -year-old pruning weight.

cMean values followed by the same letter are not significantly different by LSD test at $p \leq 0.05$. ns indicates not significant.

Table 3 Count buds, shoots, clusters, and bud fruitfulness of Pinot gris grapevines in the following season after pruning treatments.

\begin{tabular}{|c|c|c|c|c|c|c|c|c|}
\hline Treatment & $\begin{array}{c}\text { Count } \\
\text { buds/vine }\end{array}$ & $\begin{array}{c}\text { Count } \\
\text { shoots /vine }\end{array}$ & $\begin{array}{c}\text { Noncount } \\
\text { shoots/vine }\end{array}$ & $\begin{array}{c}\text { Total } \\
\text { shoots/vine }\end{array}$ & $\begin{array}{c}\text { Count } \\
\text { clusters/vine }\end{array}$ & $\begin{array}{c}\text { Noncount } \\
\text { clusters/vine }^{d}\end{array}$ & $\begin{array}{c}\text { Total } \\
\text { clusters/vine }\end{array}$ & $\begin{array}{c}\text { Bud } \\
\text { fruitfulness }\end{array}$ \\
\hline Spur pruning & $16 a^{e}$ & $16 a b$ & 7 & $23 a b$ & $28 \mathrm{a}$ & 6 & $34 a b$ & 2.0 \\
\hline 2-node hedging & $22 \mathrm{a}$ & $22 \mathrm{a}$ & 9 & $31 \mathrm{a}$ & $34 a$ & 9 & $42 \mathrm{a}$ & 1.6 \\
\hline 5-node hedging & $14 a b$ & $17 a b$ & 7 & $24 a b$ & $23 a b$ & 6 & $29 a b$ & 1.9 \\
\hline No pruning & $7 \mathrm{~b}$ & $12 b$ & 6 & $18 \mathrm{~b}$ & $12 \mathrm{~b}$ & 4 & $16 \mathrm{~b}$ & 1.7 \\
\hline$p$ value & 0.006 & 0.023 & ns & 0.028 & 0.003 & ns & 0.008 & ns \\
\hline
\end{tabular}

${ }^{a}$ Count shoots: originated from count buds retained at pruning.

bNoncount shoots: originated from buds other than count buds.

'Count clusters: borne on count shoots.

dNoncount clusters: borne on noncount shoots.

eMean values followed by the same letter are not significantly different by LSD test at $p \leq 0.05$. ns indicates not significant. 
might negatively affect fruitfulness in the following season. Similar conclusions have been reported in Washington (Keller and Mills 2007).

\section{Conclusions}

A statewide survey of winter injury in more than $30 \mathrm{cul}$ tivars confirmed the level of cold hardiness among different genotypes and its close association with published LT50s of primary buds and identified Vitis vinifera cultivars as the most cold sensitive. The extent of winter injury is primarily driven by the environment (location, lowest minimum temperature, temperature preceding the freezing event, and the acclimating conditions in the previous year) and genotype. A difference of $2{ }^{\circ} \mathrm{C}$ between two locations resulted in a 10 fold increase of bud injury on Pinot gris. Physiologically, the various pruning strategies did not affect the recovery of Pinot gris following $\sim 90 \%$ bud injury. Practically, though, when vines sustain extensive primary bud injury, hedge pruning is advantageous over nonpruning or standard spur pruning because a moderate crop can be harvested in the same year following winter injury that ensures the maintenance of vine balance and rapid retraining and reestablishment of renewal spurs in year 2 . The practice of hedge pruning to 5-node spurs is, therefore, recommended on cultivars that sustain extensive winter bud injury.

\section{Literature Cited}

Bordelon, B.P., D.C. Ferree, and T.J. Zabadal. 1997. Grape bud survival in the Midwest following the winter of 1993-1994. Fruit Var. J. 51:53-59

Dami, I.E. 2009. Update on the recent freezing events in Ohio. Ohio Grape-Wine Electronic Newsletter. 6 Feb 2009 (3):2-5.

Dami, I.E., and S. Ennahli. 2010. The 2009 winter injury and pruning adjustment of grapevines in Ohio. Abstr. 51:564A.

Dami, I.E., M.A. Ellis, D.C. Ferree, B. Bordelon, M.V. Brown, R.N. Williams, and D. Doohan. 2005. Midwest Grape Production Guide. Extension Bulletin 919, 155 pp. Ohio State University, Columbus.

Goffinet, M.C. 2001. The anatomy of low-temperature injury of grapevines. In Proceedings of the ASEV 50th Anniversary Annual
Meeting. J.M. Rantz (ed.), pp. 94-100. Am. Society for Enology and Viticulture, Davis.

Hamman, R.A., Jr., I.E. Dami, T.M. Walsh, and C. Stushnoff. 1996. Seasonal carbohydrate changes and cold hardiness of Chardonnay and Riesling grapevines. Am. J. Enol. Vitic. 47:31-36.

Howell, G.S. 2001. Sustainable grape productivity and the growth-yield relationship: A review. Am. J. Enol. Vitic. 52:165-174.

Howell, S.G. 1988. Cultural manipulation of vine cold hardiness. In Proceedings of the Second International Cool Climate Symposium for Viticulture and Oenology. R.E. Smart et al. (eds.), pp. 98-102. New Zealand Society for Viticulture and Oenology, Auckland.

Keller, M., and L.J. Mills. 2007. Effect of pruning on recovery and productivity of cold-injured Merlot grapevines. Am. J. Enol. Vitic. 58:351-357.

Kliewer, W.M., and N.K. Dokoozlian. 2005. Leaf area/crop weight ratios of grapevines: Influence on fruit composition and wine quality. Am. J. Enol. Vitic. 56:170-181.

Quamme, H.A. 1986. Use of thermal analysis to measure the freezing resistance of grape buds. Can. J. Plant Sci. 66:945-952.

Smart, R.E., and M. Robinson. 1991. Sunlight into Wine: A Handbook for Winegrape Canopy Management. Winetitles, Adelaide.

Warmund, M.R., P. Guinan, and G. Fernandez. 2008. Temperatures and cold damage to small fruit crops across the eastern U.S. associated with the April 2007 freeze. HortScience 43:1-5.

Wolf, T.K., and R.M. Pool. 1987. Factors affecting exotherm detection in the differential thermal analysis of grapevine dormant buds. J. Amer. Soc. Hort. Sci. 112:520-525

Wolf, T.K., and M.K. Cook. 1994. Cold hardiness of dormant buds of grape cultivars: Comparison of thermal analysis and field survival. HortScience 29:1453-1455.

Wolf, T.K., and J.D. Boyer. 2001. Site selection and other vine management principles and practices to minimize the threat of cold injury. In Proceedings of the ASEV 50th Anniversary Annual Meeting. J.M. Rantz (ed.), pp. 49-59. Am. Society for Enology and Viticulture, Davis.

Wolfe, W. 2001. Vine and vineyard management following low temperature injury. In Proceedings of the ASEV 50th Anniversary Annual Meeting. J.M. Rantz (ed.), pp. 101-110. Am. Society for Enology and Viticulture, Davis.

Zabadal, T., I.E. Dami, M. Goffinet, T. Martinson, and M. Chien. 2007. Winter Injury to Grapevines and Methods of Protection. Extension Bulletin E2930. Michigan State University, East Lansing. 